Sharif University of Technology
Scientia Iranica
Transactions E: Industrial Engineering
hCIENTIA

\title{
A holistic framework for lot sizing problem for fast-moving perishable products
}

\author{
A. Kumar Sinha and A. Anand* \\ Department of Mechanical Engineering, Shri Mata Vaishno Devi University, Katra, Jammu and Kashmir, 182320, India.
}

Received 17 November 2017; received in revised form 29 October 2018; accepted 31 December 2018

\section{KEYWORDS}

Lot sizing;

Fast-moving perishable products;

Supply chain;

Cross-dock;

Truckload discounts.

\begin{abstract}
One of the major challenges that manufacturing companies face today is the issue of addressing various aspects of perishable products in a supply chain environment. To address this issue, the integrated lot sizing problem for a perishable product was investigated in the present work. The problem was modeled as a single-vendor multiplebuyer system. A variant of the truckload discount scheme was applied, and the proposed model was formulated as a Mixed Integer Program (MIP). The traditional warehouses were replaced by 'cross-docks', and situations featuring beneficial cross-docking are highlighted. The problem of fleet selection was addressed, and various strategies for minimizing the vendor cost were also highlighted for centralized and decentralized supply chains. Sensitivity analysis was then carried out on various input parameters such as setup cost at the plant, variable transportation cost, fixed transportation cost, setup cost per order, holding cost, and lost cost that underscore the significant impact of economies of scale in transportation on the total supply chain cost. The analysis of a lead timecost trade-off revealed that alternate modes of transportation that significantly reduce the lead time of transportation could be explored, thereby minimizing the total supply chain cost.
\end{abstract}

(C) 2020 Sharif University of Technology. All rights reserved.

\section{Introduction}

In today's competitive manufacturing conditions, managers need to fulfill the needs of customers at low costs with less environmental impact. Due to the growing technological advancements in the manufacturing world, customers' requirements vary at a rapid rate very frequently with the increased expectation level of customers [1]. The design and implementation of an appropriate Supply Chain (SC) network to a greater

\footnotetext{
*. Corresponding author. Fax: +9101991285687 E-mail addresses: amitsinha5050@gmail.com (A. Kumar Sinha); anand.ankush13@gmail.com (A. Anand)
}

extent may provide competitive advantages for manufacturing industries, thus ensuring sustainability in the global competitive environment [2]. In the current time period, the concept of $\mathrm{SC}$ network has shifted from the traditional SC environment. Nowadays, SC is an integral system of raw materials, material procurement, suppliers, manufacturing processes, assembly, dispatch, logistics, inventory, cross-docks, warehouses, end customers, and recycling of the product [3]. The SC environment is also defined as an effective management of all components/partners in the SC network including the transportation and replenishment of raw materials either inside the manufacturing shop floor or shipment of finished goods and transportation decisions (mode of shipment, lot sizing, and fleet selection) for yielding competitive advantages for all individual 
components/partners [4,5].

$\mathrm{SC}$ network design mainly consists of three levels: strategic, tactical, and operational decisions [6]. Strategic decisions mainly emphasize production, assembly, and distribution to fulfill the demand of end customers. Tactical decisions describe the management policy for the flow of materials, decisions related to various production levels, assembly section, inventory control, and lot sizes. Decisions at the operational level deal with the scheduling of different operations of SC network to make a responsive SC design including coordination in a logistic network to ensure the on-time delivery of a product to end customers at low costs with the least environmental impacts $[7,8]$. However, a logistic network, which is a part of the green SC network, is one of the major challenging tasks for every manufacturing industry.

Moreover, perishability is one of the key issues in a $\mathrm{SC}$ environment. The integration of production, distribution, inventory, and transportation of perishable products in the $\mathrm{SC}$ environment is one of the major thrust areas for all developing and developed countries throughout the globe, thus focusing on the design of a holistic framework based on the lot sizing problem for fast-moving perishable products. On the one hand, decaying products do not have any shelf life and, on the other hand, perishable products possess maximum service life. Therefore, after the expiry of a product or during its decaying, fast-moving perishable products have a high environmental impact (pollution), which is a major concern for optimizing the lot sizing problem for perishable products. Meanwhile, during degradation and after the expiry date of perishable products, they emit a high volume of environmental pollution and green house emission; such a concern has motivated the researchers and practitioners to formulate a holistic framework to handle the issues of lot sizing problems. Strict government regulations and policies of international organizations have motivated us to investigate perishable products through the application of optimal lot sizing and fleet concept in a $\mathrm{SC}$ environment so as to not only control the economic gain but also deliver environmentally friendly products.

The lot sizing problem for perishable products provides a tactical decision that plays an important role in the performance of the closed-loop SC network and, also, facilitates competitive advantages for all SC network partners [9]. Tactical decision also affects other decisions at strategic and operational levels; thus, the decision-maker should always keep in mind the complexity of the lot sizing problem for perishable products while settling other issues related to SC network [10]. Choosing a suitable mode of shipment, lot size, and fleet constitutes the main considerations in the SC network. These decisions are the most important issues for decision-makers. Slight changes in these decisions can either favorably or unfavorably affect other decisions starting from the top level to the bottom level of the $\mathrm{SC}$ environment. The availability of different fleet alternatives such as full truck load, half truck load, etc. in the global market facilitates the new process customization [11]. Meanwhile, for satisfying customer demands and making a responsible SC network design, it is necessary to optimize the lot size for facilitating a flexible logistic network design [12].

Literature survey reveals that there is a significant research gap between the old and new practices for handling the lot sizing problem of perishable goods. Available literature survey [13-22] in this domain mainly focuses on the production and inventory of perishable products. Now, due to the intensifying global competitive environment, it is necessary to handle perishable products with low costs and less environmental impact. It can be implied that the problem of lot sizing, which includes proper fleet selection for perishable products, is a challenging task for practitioners and researchers.

To address the above discussed issues of the lot sizing problem for perishable products, this study presents the following highlights:

- A holistic framework of the lot sizing problem is developed for perishable products;

- A fleet selection model for identifying optimum truckload capacity for perishable products is formulated;

- The benefits of cross-docking over warehouses are highlighted;

- Various strategies to minimize the vendor cost are discussed;

- Validation of the proposed framework through a case study with sensitivity analysis is carried out.

The rest of the paper is summarized as follows. Section 2 deals with literature survey of various strategies used for perishable products. Section 3 explains the proposed model. Computational results of the case study are discussed in Section 4 that also deals with sensitivity analysis, facilitating decision-making. Fleet selection, centralized versus decentralized SC for perishable products, and significance of cross-docks are explained in Section 5. Finally, Section 6 presents the conclusions and future research in this domain.

\section{Literature review}

A review of the literature on the $\mathrm{SC}$ network that involves the lot sizing problem for perishable products was carried out; as a result, the following components were found to have been highly focused: 
(i) Green SC;

(ii) Perishability;

(iii) Lot sizing problem;

(iv) Fleet selection.

Therefore, in this section, each component is highlighted with motivational factors so as to identify the research gap in this domain.

\subsection{Green $S C$}

Fathollahi-Fard et al. [23] formulated a two-stage stochastic multi-objective closed-loop SC model based on virus colony search algorithm by considering environmental and economic criteria. An integrated approach at three levels of manufacturers, distributors, and collectors, known as a tri-level programming model, was initiated by Fathollahi-Fard et al. [24] for designing a location-allocation problem in a closedloop SC network environment. A sustainable SC network model was considered by Musavi and BozorgiAmiri [25]. These researchers described a multiobjective mixed integer programming model, where the main objectives include reducing Total Transportation Costs (TTCs), promoting the quality of products, and ensuring their freshness on delivery.

A bi-level meta-heuristic based partial interdiction model was proposed by Fathollahi-Fard and Hajiaghaei-Keshteli [26] that involves:

(a) A defense system for protecting facilities,

(b) Total SC cost of supplying the defense system.

Hajiaghaei-Keshteli and Fathollahi-Fard [27] developed an efficient and effective stochastic model for incorporating the behavior of a distribution network in the $\mathrm{SC}$ environment. The authors developed a decisionmaking model based on Stackelberg game between distribution centers and customer zones.

Samadi et al. [28] developed three heuristics to generate the first population of genetic algorithm. The researchers also proposed red dear algorithm for solving the sustainable SC network model. A simple fourstep based social engineering optimizer was developed by Fathollahi-Fard et al. [29], which is more efficient and effective than the population-based meta-heuristic algorithms such as genetic algorithm, particle swarm optimization, ant colony optimization, etc. in resolving the complex nature of green SC networks.

Fathollahi-Fard et al. [29] formulated a hybrid meta-heuristic algorithm based closed-loop SC network model that incorporates economic and social factors. They made an attempt to consider both economic and social factors simultaneously in the same SC network model.

\subsection{Perishability}

Over the past few years, it has been observed that more than 100 million population of the European Union (EU) are facing the problem of poverty including finding food, while $35 \%$ of perishable food at the supermarket in the EU becomes unfit for use [30]. This has essentially motivated us to develop a holistic framework for perishable products to address the issue. Optimizing the lot sizing problem of perishable products would be one of the solutions to this type of problems. In this regard, Goyal and Giri [31] defined two types of deteriorating products: one with maximum service lifetime called perishable product and the other with no shelf life, known as decaying products. The modeling of deteriorating inventory was carried out by Goyal and Giri [31].

An initial investigation of the deteriorating inventory model for perishable products was carried out by Ghare and Schrader [32]. The model proposed by Ghare and Schrader [32] was based on the principle of a constant decay rate, which cannot be applied in realistic situations. Therefore, Nahmias (1982) [33] modified the proposed model of Ghare and Schrader [32] and considered the unsteady deteriorating rate. Later, Hsu (2000) [34] developed a new deteriorating inventory model, based on which it was assumed that the stock deteriorating rate was dependent upon the age of stock and their production time, simultaneously. Economic Lot Size (ELS) model for perishable products at a constant decay rate was proposed by Abad (2000) [35]. Again, a new realistic ELS model for perishable products was developed by Abad (2003) [36], where Abad considered a lot of realistic situations including the exponential decay rate, age-dependent inventory function, lost cost, back-ordering, etc. Teng et al. [37] formulated a realistic perishable model by considering expiration date as a function of the number of deteriorating products.

Hiassat et al. [38] demonstrated a real-life location-inventory-routine model for perishable products. Sahebjamnia et al. [39] developed a sustainable SC model of tire by considering economic, manufacturing, logistic, and environmental factors.

\subsection{Lot sizing problem}

In view of globalization and growing use of internet of things (IoT), suppliers and decision-makers are facilitated to use the concept of lot sizing problem in different fleet selection modes. Optimization-based decisions of lot sizing directly affect the performance and productivity of a manufacturing industry by minimizing the setup, production, inventory, and logistic costs [40]. High variation in customer demands needs a responsible SC management, which can be achieved through a proper utilization of the concept of optimal lot-size problem with optimal fleet selection such as 
a discount in logistics or half and full truck load concept.

Chandra and Fisher [13] concluded that the proper integration of production and distribution systems could significantly reduce $3 \%$ to $20 \%$ of total operating costs in an industry that produces various products under uncertain environment. Yano and Lee [41] suggested a stochastic model for determining lot sizes during the production and procurement of products, where both production and demands are uncertain. Karimi et al. [40] identified eight attributes that affect the lot-size model. These attributes include planning horizon, number of levels, number of products, capacity constraints, demand, setup structure, and inventory management. On the basis of these attributes, the authors investigated a capacitated single-level lot sizing model. An empirical study of joint economic lot sizing problem was carried out by Ben-Daya et al. [42]. Having conducted a review of 56 research papers, Robinson et al. [43] developed the taxonomy of deterministic dynamic lot sizing problem. The economic lot sizing problem for perishable products was modeled by Önal et al. [44] by considering first-expiration-first-out, lastexpiration-first-out, first-in-first-out, and last-in-lastout models.

An attempt to present an integrated production and inventory model of the lot sizing problem was made by Lee (2005) [45]. Lee (2005) [45] attempted to minimize the total ordering cost, setup cost, and inventory cost by adjusting coordination between production and inventory lot sizing model. However, the work of Lee (2005) [45] was extended by Pal et al. [46]. Pal et al. [46] suggested an integral approach of procurement, production, and shipment model for minimizing the total SC cost. Önal (2016) [47] attempted to formulate an economic lot sizing model of perishable products by integrating optimal logistic and inventory costs.

\subsection{Fleet selection}

Generally, the cost of a full truck is almost equivalent to that of an empty truck. This aspect has motivated us to optimize the truck load capacity so that the manufacturers could apply the concept of different discount schemes, viz full truck load or half truck load. Various available discount schemes during logistics that motivate manufacturers to avail of the facility were discussed by Benton and Park [48]; Nahmias and Cheng [49]. Nahmias and Cheng [49] identified three different discount schemes:

(i) All unit discount schemes;

(ii) Incremental discount scheme;

(iii) Truckload discount scheme.

A tri-level quantity discount model of the SC network under price sensitivity was examined by Ke and Book- binder [50]. In the proposed model, the researchers have considered not only the discount policy for supplier and customer but also the less-than truckload carrier scheme in both centralized and decentralized schemes. A multi-objective closed-loop sustainable SC network model based on logistic discount supposition was formulated by Fathollahi-Fard and HajiaghaeiKeshteli [7]. Since the 1990s, researchers have shown that discount available due to fleet selection would decrease the price of perishable products at the hand of end customers by decreasing the logistic cost of manufacturers [51,52].

Table 1 shows a comparative literature survey conducted on the economic lot sizing problem for perishable products. Based on Table 1, the following research gaps have been observed:

- Generic lot sizing model cannot be implemented for perishable products;

- Most of the papers have used the lot sizing problem at the inventory level only;

- Decision of fleet selection such as half truck load, less-than truckload, or discount in logistics for perishable products still needs to be explored;

- Most of the papers have pointed out the lack of production, distribution, and inventory approaches to the lot sizing problem for perishable products.

On the basis of the above presented literature survey, it is evident that production, distribution, and inventory model based on the lot sizing problem for perishable products needs more critical emphasis. Therefore, a holistic framework of the lot sizing problem for perishable products is thus imperative for both customers and suppliers in an SC environment. In this regard, the multi-period economic lot sizing problem has been excavated by practitioners and researchers.

\section{Model formulation}

The proposed two-stage SC network for perishable products is shown in Figure 1. In this network, there are " $P$ " number of manufacturing plants, " $C$ " number of cross-docks, and " $M$ " number of markets. This network is framed for all " $T$ " periods of time. Some of the assumptions of the proposed framework are as follows:

(i) In the $t$ th period of time zone, the demand arising from the market is known and will be fulfilled in the initial time zone, after which the situation becomes uncertain;

(ii) Backordering is not allowed; 
Table 1. Comparative literature survey based on economic lot sizing problem for perishable products.

\begin{tabular}{|c|c|c|c|c|c|}
\hline Literature survey & $\begin{array}{c}\text { Supply chain } \\
\text { network }\end{array}$ & $\begin{array}{c}\text { Economic Lot } \\
\text { size problem }\end{array}$ & $\begin{array}{c}\text { Fleet } \\
\text { selection }\end{array}$ & $\begin{array}{c}\text { Perishable } \\
\text { product }\end{array}$ & $\begin{array}{c}\text { Solution } \\
\text { methodology }\end{array}$ \\
\hline Abad (2000) [35] & $\checkmark$ & $\begin{array}{l}\text { - Partial } \\
\text { backordering } \\
\text { - Lost sale }\end{array}$ & $x$ & $\begin{array}{l}\text { - Exponential } \\
\text { decay }\end{array}$ & $\begin{array}{l}\text { - Nonlinear model } \\
\text { - Taylor's series } \\
\text { expansion }\end{array}$ \\
\hline Abad (2003) [36] & $\checkmark$ & $\begin{array}{l}\text { - Pricing } \\
\text { - Finite production } \\
\text { - Partial } \\
\text { backordering } \\
\text { - Lost sale }\end{array}$ & $x$ & $\begin{array}{l}\text { - Exponential } \\
\text { decay }\end{array}$ & $\times$ \\
\hline Amorim et al. [17] & $x$ & $\begin{array}{c}\text { - Production \& } \\
\text { distribution }\end{array}$ & $x$ & $\checkmark$ & $x$ \\
\hline Azadeh et al. [20] & $x$ & $\begin{array}{l}\text { - Vehicle routine } \\
\text { - Inventory }\end{array}$ & $x$ & $\begin{array}{l}\text { - Exponential } \\
\text { decay }\end{array}$ & - Genetic algorithm \\
\hline Ben-Daya et al. [42] & $\checkmark$ & $\checkmark$ & $x$ & $x$ & $x$ \\
\hline Bruno et al. [12] & $x$ & $\begin{array}{l}\text { - Capacitated lot } \\
\text { sizing problem } \\
\text { - Inventory }\end{array}$ & $\times$ & $\times$ & $x$ \\
\hline $\begin{array}{l}\text { Chandra and } \\
\text { Fisher [13] }\end{array}$ & $\begin{array}{l}\text { - Coordinating } \\
\text { between } \\
\text { production } \\
\text { \& planning }\end{array}$ & $x$ & $\times$ & $x$ & $x$ \\
\hline De La Vega et al. [11] & $\checkmark$ & $\begin{array}{l}\text { - Joint } \\
\text { transportation } \\
\text { \& inventory }\end{array}$ & $\begin{array}{l}\text { - Full truck } \\
\text { load } \\
\text { - Less than } \\
\text { truck load }\end{array}$ & $\times$ & $\begin{array}{l}\text { - Multi criteria } \\
\text { decision making }\end{array}$ \\
\hline Devika et al. [10] & $\begin{array}{l}\text { - Sustainable } \\
\text { close loop } \\
\text { supply chain }\end{array}$ & $x$ & $x$ & $x$ & $\begin{array}{l}\text { - Mixed integer } \\
\text { programming } \\
\text { model } \\
\text { - Imperialist } \\
\text { competitive } \\
\text { algorithm }\end{array}$ \\
\hline Dolgui et al. [21] & $\checkmark$ & $\begin{array}{l}\text { - Try to integrate } \\
\text { production, } \\
\text { inventory, and } \\
\text { distribution }\end{array}$ & $\begin{array}{l}\text { - Full truck } \\
\text { load } \\
\text { - Half truck } \\
\text { load }\end{array}$ & $\checkmark$ & $\begin{array}{l}\text { - Non revisiting } \\
\text { genetic } \\
\text { algorithm }\end{array}$ \\
\hline Goyal and Giri [31] & $\times$ & - Inventory & $x$ & $\checkmark$ & \\
\hline
\end{tabular}


Table 1. Comparative literature survey based on economic lot sizing problem for perishable products (continued).

\begin{tabular}{|c|c|c|c|c|c|}
\hline Literature survey & $\begin{array}{l}\text { Supply chain } \\
\text { network }\end{array}$ & $\begin{array}{l}\text { Economic Lot } \\
\text { size problem }\end{array}$ & $\begin{array}{c}\text { Fleet } \\
\text { selection }\end{array}$ & $\begin{array}{c}\text { Perishable } \\
\text { product }\end{array}$ & $\begin{array}{c}\text { Solution } \\
\text { methodology }\end{array}$ \\
\hline $\begin{array}{l}\text { Hajiaghaei-Keshteli, } \\
\text { and } \\
\text { Fathollahi-Fard [2] }\end{array}$ & $\begin{array}{l}\text { Sustainable } \\
\text { close loop } \\
\text { supply chain }\end{array}$ & - Transportation & $\begin{array}{l}\text { - Discount } \\
\text { supposition }\end{array}$ & $x$ & $\begin{array}{l}\text { - Keshtel genetic } \\
\text { algorithm }\end{array}$ \\
\hline Hiassat et al. [38] & & $\begin{array}{l}\text { - Location } \\
\text { inventory } \\
\text { routine model }\end{array}$ & & $\checkmark$ & - Genetic algorithm \\
\hline Hsu (2000) [34] & $\checkmark$ & $\begin{array}{l}\text { - Production } \\
\text { - Inventory }\end{array}$ & $\times$ & $\checkmark$ & $\begin{array}{l}\text { - Dynamic } \\
\text { programming } \\
\text { algorithm }\end{array}$ \\
\hline Karimi et al. [40] & $\checkmark$ & $\begin{array}{l}\text { - Single level lot } \\
\text { sizing problem } \\
\text { - Factors affecting } \\
\text { lot sizing }\end{array}$ & $x$ & $\times$ & $\begin{array}{l}\text { - Integer } \\
\text { programming } \\
\text { software }\end{array}$ \\
\hline Ke and Bookbinder [50] & $\checkmark$ & $x$ & $\begin{array}{l}\text { - Full truck } \\
\text { load } \\
\text { - Less than } \\
\text { truck load }\end{array}$ & $\times$ & $\begin{array}{l}\text { - Optimization } \\
\text { approach }\end{array}$ \\
\hline Ma et al. [19] & $x$ & $\begin{array}{l}\text { - Time dependent } \\
\text { vehicle routine } \\
\text { problem }\end{array}$ & $x$ & $\checkmark$ & $\begin{array}{l}\text { Hybrid Ant colony } \\
\text { optimization }\end{array}$ \\
\hline $\begin{array}{l}\text { Musavi and } \\
\text { Bozorgi-Amiri [25] }\end{array}$ & $\checkmark$ & $x$ & $x$ & $\checkmark$ & $\begin{array}{l}\text { Non-dominated } \\
\text { Sorting } \\
\text { Genetic } \\
\text { Algorithm-II } \\
\text { (NSGA-II) }\end{array}$ \\
\hline Önal et al. [44] & $\checkmark$ & & $x$ & $\checkmark$ & - Heuristic \\
\hline Önal [47] & $\checkmark$ & $\begin{array}{l}\text { - Economic lot } \\
\text { sizing problem }\end{array}$ & $x$ & $\checkmark$ & - Heuristic \\
\hline Pal et al. [46] & $\checkmark$ & $\begin{array}{l}\text { - Integration of } \\
\text { procurement, } \\
\text { production, and } \\
\text { shipment without } \\
\text { considering } \\
\text { lot sizing }\end{array}$ & $x$ & $\times$ & - Swarm heuristics \\
\hline
\end{tabular}


Table 1. Comparative literature survey based on economic lot sizing problem for perishable products (continued).

\begin{tabular}{|c|c|c|c|c|c|}
\hline Literature survey & $\begin{array}{c}\text { Supply chain } \\
\text { network }\end{array}$ & $\begin{array}{l}\text { Economic Lot } \\
\text { size problem }\end{array}$ & $\begin{array}{c}\text { Fleet } \\
\text { selection }\end{array}$ & $\begin{array}{c}\text { Perishable } \\
\text { product }\end{array}$ & $\begin{array}{c}\text { Solution } \\
\text { methodology }\end{array}$ \\
\hline Tang et al. [37] & $\checkmark$ & $\begin{array}{l}\text { - Inventory lot } \\
\text { sizing problem }\end{array}$ & $x$ & $\begin{array}{l}\text { - Deterioration } \\
\text { rate increases } \\
\text { as the date of } \\
\text { expiry increases }\end{array}$ & $x$ \\
\hline Proposed model & $\checkmark$ & $\checkmark$ & $\checkmark$ & $\checkmark$ & $\begin{array}{r}- \text { Mixed integer } \\
\text { programming }\end{array}$ \\
\hline
\end{tabular}
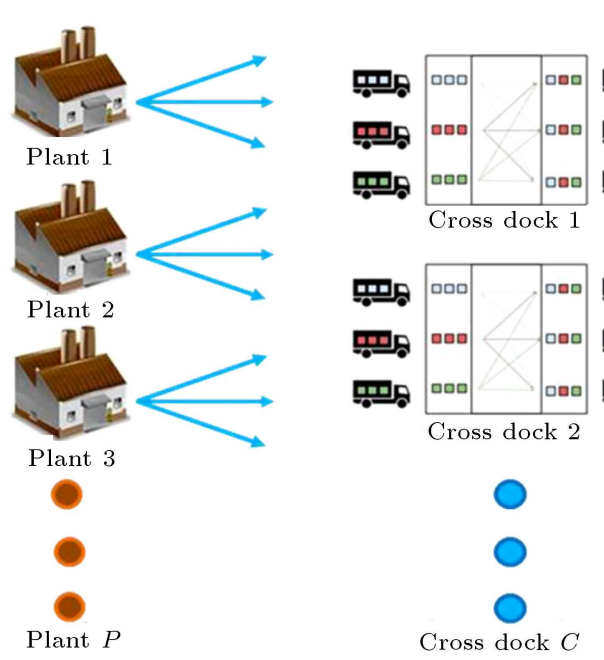
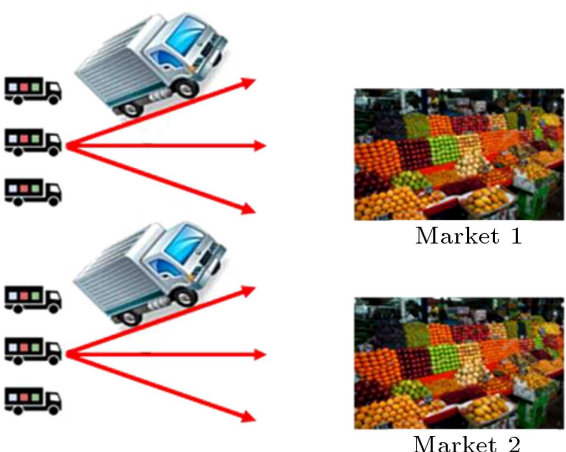

Market 1

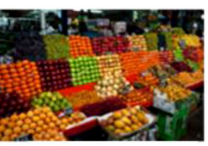

Market 2

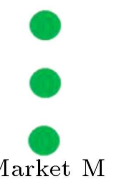

Figure 1. Two-stage supply chain network for perishable products.

(iii) The production capacity of manufacturing plants, the capacity of cross-docks, and maximum demand of markets will not change with respect to time zone.

The model parameters are as follows:

$p \quad$ Number of plants, $p=1,2, \cdots p$

$c \quad$ Number of cross-docks, $c=1,2, \cdots c$

$m \quad$ Number of markets, $m=1,2, \cdots m$

$t \quad$ Time periods, $t=1,2, \cdots t$

$T C_{p c}^{1} \quad$ Transportation cost per unit production per unit length for carrying items from plant ' $p$ ' to cross-dock ' $c$ '

$T C_{c m}^{2} \quad$ Transportation cost per unit product per unit length for carrying items from cross-dock ' $c$ ' to market ' $m$ '

$L_{p c}^{1} \quad$ Distance between plant ' $p$ ' and cross-dock ' $c$ '

$L_{c m}^{1} \quad$ Distance between cross-dock ' $c$ ' and market ' $m$ '

$D_{m t} \quad$ Demand of market ' $m$ ' at time ' $t$ '

$H_{c} \quad$ Handling cost per unit at cross-dock ' $c$ '

$F C_{f} \quad$ The fixed cost of hiring per truck in FTL
$F C_{h} \quad$ The fixed cost of hiring per truck in HTL

$H C_{m} \quad$ Holding cost per unit in the market $m$

$P C_{p}^{1} \quad$ Production capacity of plant ' $p$ '

$P C_{c}^{2} \quad$ Capacity of cross dock ' $c$ '

$P C{ }_{m}^{3} \quad$ Capacity of market ' $m$ '

$L C \quad$ Lost cost per unit

$S C_{p} \quad$ Setup cost per unit in plant ' $p$ '

$O C_{m} \quad$ Order cost per unit in the market ' $m$ '

$S L \quad$ Service level

ETC Expected total cost

$\alpha_{s t} \quad$ The fraction of units produced in period $s$ that deteriorate in period $t$

$\sigma_{m t} \quad$ Variance in demand of the market $m$ in period $t$

\section{Decision variables}

$N_{p c t}^{f 1} \quad$ Number of FTL trucks transported from plant $p$ to cross-dock $c$ in period $t$

$N_{p c t}^{h 1} \quad$ Number of HTL trucks transported from plant $p$ to cross-dock $c$ in period $t$ 
$N_{c m t}^{f 2} \quad$ Number of FTL trucks transported from cross-dock $c$ to market $m$ in period $t$

$N_{c m t}^{h 2} \quad$ Number of HTL trucks transported from cross-dock $c$ to market $m$ in period $t$

$P A_{\text {pct }}^{f 1} \quad$ A partial full truckload of units transported from plant $p$ to cross-dock $c$ in period $t$

$P A_{p c t}^{h 1} \quad$ A partial half truckload of units transported from plant $p$ to cross-dock $c$ in period $t$

$P A_{c m t}^{f 2} \quad$ Partial full truckload transported from cross-dock $c$ to market $m$ in period $t$

$P A_{c m t}^{h 2} \quad$ Partial half truckload transported from cross-dock $c$ to market $m$ in period $t$

$U_{c m t}^{1} \quad$ Units shipped from cross-dock $c$ to market $m$ in period $t$

$U_{p c t}^{2} \quad$ Units shipped from plant $p$ to cross-dock $c$ in period $t$

$U_{m s t}^{3} \quad$ Units produced in period $s$ held as inventory in period $t$ in market $m$

$U_{m s t}^{4} \quad$ Units produced in period $s$ used to satisfy the demand of market $m$ in period $t$

$O P_{m t} \quad$ Order placed by market $m$ at time ' $t$ '

$P O_{p t} \quad$ Production taking place at plant $p$ at time ' $t$ '

If any order is placed from the market, then $O P_{m t}=1$; else, $O P_{m t}=0$.

In the same way, if production is carried out at the plant, then $P O_{p t}=1$; else, $P O_{p t}=0$.

The proposed model is based on Dolgui et al. [21]. Dolgui et al. [21] illustrated the SC network for perishable products. This study considered the highlights of Dolgui et al. [21] and further investigated the same highlights through sensitivity analysis using commercial software; moreover, the results obtained in this manuscript will facilitate decision-makers for effective decision-making concerning the lot sizing problem for perishable products under different fleet selection environments.

In this model, variable lifetime of inventory has been considered. It has been assumed that the deterioration of units follows the exponential function (see Eq. (1)). The rate of deterioration function with constants $A$ and $B$ is as follows:

$$
\operatorname{Det}(t)=A e^{t / B} \text {. }
$$

The values of constants $A$ and $B$ could be changed to model the deterioration of different types of products.
The fraction of units produced in period ' $s$ ' that deteriorate in period ' $t$ ' is:

$$
\alpha_{s t}=\int_{t=t-s}^{t=t-s+1} \operatorname{Det}(t) d t .
$$

For a perishable product, the rate of deterioration increases exponentially with time, i.e.:

$$
\alpha_{s t}>\alpha_{s+1, t} ; \quad \text { where } \quad s<t .
$$

Unit produced in period ' $s$ ' held as inventory in period ' $t$ ' in market ' $m$ ' will deteriorate with increasing time, i.e.:

$$
U_{m s t}^{3}>U_{m s t^{*}}^{3} ; \quad \text { where } t^{*}>t .
$$

Total holding cost plus lost cost per unit produced in period ' $s$ ' held as an inventory in period ' $t$ ' will be expressed in Eq. (5):

$$
\begin{aligned}
T H O\left(\alpha_{s t}, U_{m s t}^{3}\right)= & \left\{\left(\mathrm{HO}_{m} \times\left(1-\alpha_{s t}\right) \times U_{m s t}^{3}\right)\right. \\
& \left.+\left(L C \times \alpha_{s t} \times U_{m s t}^{3}\right)\right\} .
\end{aligned}
$$

TTC will be a function of the number of units shipped from plant ' $p$ ' to cross-dock ' $c$ ' in period ' $t$ ' $\left(U_{p c t}^{2}\right)$, i.e., $\operatorname{TTC}\left(U_{p c t}^{2}\right)$.

Total transportation cost $\left(T T C\left(U_{p c t}^{2}\right)\right)=$ Fixed cost of hiring a single truck $(F C)+$ cost of transportation per unit $\left(T C_{p c}^{1}\right) \times$ number of units shipped from plant ' $p$ ' to cross-dock ' $c$ ' in period ' $t$ ' $\left(U_{p c t}^{2}\right)$ :

$$
T T C\left(U_{p c t}^{2}\right)=F C+T C_{p c}^{1} \times U_{p c t}^{2} .
$$

Fixed cost of hiring a single truck $(F C)$ can be determined on the basis of truckload, i.e., $U_{p c t}^{2}$. It is implied that if the truck carries less than HTL, then the fixed cost of hiring a single truck $(F C)$ will be equal to the fixed cost of hiring per truck in $H T L\left(F C_{h}\right)$; in addition, if the truck carries more than HTL and less than or equal to Full Track Load (FTL), then the fixed cost of hiring a single truck $(F C)$ will be equal to the fixed cost of hiring per truck in $F T L\left(F C_{f}\right)$, which is explained in Eqs. (7) and (8):

$$
\begin{aligned}
& F C=F C_{h} ; \quad \text { If } 0<U_{p c t}^{2} \leq H T L, \\
& \begin{array}{l}
F C=F C_{f} ; \quad \text { If } H T L<U_{p c t}^{2} \leq F T L . \\
\text { Effective variance in demand }\left(\sigma_{m L t}\right) \\
\quad=\text { Variance in demand }\left(\sigma_{m t}\right) \\
\quad \times\left(\text { Lead time }\left(L_{t}\right)\right)^{1 / 2},
\end{array}
\end{aligned}
$$

Safety stock $=\left(\sigma_{m L t}\right) \times S L$.

The Expected Total Cost (ETC) is modeled in Eq. (11) 
as an objective function, which is a function of the total cost of production, transportation, inventory, and loss in deterioration. Now, the objective of the proposed model is to determine the optimum value of the ETC for perishable products.

$$
\min \left\{\begin{array}{l}
\sum_{p, t}\left(S C_{p}\right) \times\left(P O_{p t}\right) \rightarrow I \\
+\sum_{p, c, t}\left\{\left(T C_{p c}^{1}\right) \times\left(L_{p c}^{1}\right) \times\left(U_{p c t}^{2}\right)\right\} \rightarrow I I \\
+\sum_{p, c, t}\left\{\left(T C_{p c}^{2}\right) \times\left(L_{p c}^{1}\right) \times\left(U_{c m t}^{1}\right)\right\} \rightarrow I I I \\
+\sum_{p, c, t}\left\{\left(F C_{f}\right) \times\left(N_{p c t}^{f 1}\right)\right\} \rightarrow I V \\
+\sum_{c, m, t}\left\{\left(F C_{f}\right) \times\left(N_{c m t}^{f 2}\right)\right\} \rightarrow V \\
+\sum_{p, c, t}\left\{\left(F C_{h}\right) \times\left(N_{p c t}^{h 1}\right)\right\} \rightarrow V I \\
+\sum_{c, m, t}\left\{\left(F C_{h}\right) \times\left(N_{c m t}^{h 2}\right)\right\} \rightarrow V I I \\
+\sum_{p, c, t}\left\{\left(H H_{c}\right) \times\left(U_{p c t}^{2}\right)\right\} \rightarrow V I I I \\
+\sum_{m, t}\left\{\left(O C_{m}\right) \times\left(O P_{m t}\right)\right\} \rightarrow I X \\
+\sum_{m, t} \sum_{s-1}\left\{\left\{(L C) \times\left(\alpha_{m s t}\right)\right\}\right\} \rightarrow X \\
+\sum_{m, t} \sum_{s-1}\left\{\left\{\left(H O_{m}\right) \times\left(1-\alpha_{m s t}\right) \times U_{m s t}^{3}\right\}\right\} \rightarrow X I
\end{array}\right\}
$$

Breakup of the expected total cost which is illustrated in Eq. (11) can be explain as below:

I. Total setup cost at plant;

II. Total transportation cost shipped from plant to cross-dock;

III. Total transportation cost shipped from crossdock to the market;

IV. Total fixed cost of hiring a truck with FTL shipped from plant to cross-dock;

V. Total fixed cost of hiring a truck with FTL shipped from cross-dock to cross-dock;

VI. Total fixed cost of hiring a truck with HTL shipped from plant to cross-dock;

VII. Total fixed cost of hiring a truck with HTL shipped from cross-dock to cross-dock;

VIII. Total handling cost at cross-dock;

IX. Total order cost in the market;

$\mathrm{X}$. Total lost cost due to deterioration;

XI. Total loss in holding cost due to deterioration in inventory.

Now, some of the constraints are given below:

Capacity constraint for the plant is expressed in Eq. (12):

$$
\sum_{c=1}^{C} U_{p c t}^{2} \leq P C_{p}^{1} \quad \forall p, t .
$$

Capacity constraint for cross-dock is expressed in Eq. (13):

$$
\sum_{p=1}^{P} U_{p c t}^{2} \leq P C_{c}^{2} \quad \forall c, t .
$$

Capacity constraint for the market is expressed in Eq. (14):

$$
\sum_{p=1}^{P} U_{p c t}^{2} \leq U_{c m t}^{1} \quad \forall c, t
$$

The constraint used for satisfying an order placed by the market as compared to that shipped from crossdock to the market is expressed in Eq. (15):

$$
\sum_{c=1}^{C} U_{c m t}^{1} \leq\left(P C_{m}^{3}\right) \times\left(O P_{m t}\right) .
$$

The number of units shipped from cross-dock to the market can satisfy the demand of the market, and the rest will be kept as inventory and expressed in Eq. (16):

$$
\sum_{c=1}^{C} U_{c m t}^{1}-U_{m s t}^{4}=U_{m s t}^{3} \quad \forall c, t .
$$

The balancing of inventory after considering the deterioration in each period can be expressed in Eq. (17):

$$
\left(1-\alpha_{m s t-1}\right) U_{m s t-1}^{3}-U_{m s t}^{4}=U_{m s t}^{3} \quad \forall m, t, s .
$$

The number of units produced at the plant must satisfy the demand of the market (since backlogging is not allowed), as expressed in Eq. (18):

$$
\sum_{s=1}^{t} U_{m s t}^{3} \geq D_{m t} \quad \forall m, t
$$

In any period of time, not only does each market maintain a safety stock, i.e., minimum level of inventory, but also inventory should not exceed the maximum capacity; this constraint is expressed in Eq. (19):

$$
\left\{\left(\sigma_{m L t}\right) \times(S L)\right\} \leq \sum_{s=1}^{t} U_{m s t}^{3} \leq P C_{m}^{3} \quad \forall m, t .
$$

The number of FTL trucks transported from plant ' $p$ ' to cross-dock ' $c$ ' in period ' $t$ ' is calculated through Eq. (20):

$$
N_{p c t}^{f 1}=\left\lfloor\frac{U_{p c t}^{2}}{F T L}\right\rfloor \quad \forall p, c, t .
$$

The number of FTL trucks transported from cross-dock 
' $c$ ' to market ' $m$ ' in period ' $t$ ' is calculated through Eq. (21):

$$
N_{c m t}^{f 2}=\left\lfloor\frac{U_{c m t}^{1}}{F T L}\right\rfloor \quad \forall c, m, t .
$$

The number of HTL trucks transported from plant ' $p$ ' to cross-dock ' $c$ ' in period ' $t$ ' is calculated through Eq. (22):

$$
N_{p c t}^{h 1}=\left\lceil\frac{\left\{U_{p c t}^{2} / F T L\right\}}{H T L}\right\rceil \quad \forall p, c, t .
$$

The number of HTL trucks transported from crossdock ' $c$ ' to market ' $m$ ' in period ' $t$ ' is calculated through Eq. (23):

$$
N_{c m t}^{h 2}=\left\lceil\frac{\left\{U_{c m t}^{1} / F T L\right\}}{H T L}\right\rceil \forall c, m, t,
$$

where:

$$
\begin{aligned}
& \lfloor x\rfloor \Rightarrow \text { Greatest integer less than ' } x \text { ', } \\
& \lceil x\rceil \Rightarrow \text { Least integer hreater than ' } x \text { '. }
\end{aligned}
$$

The linearization of the proposed model: The proposed model is nonlinear in nature. Therefore, it is a common process to make it linear (Eqs. (24)-(27)). In this respect, the following are assumed: $Z$ : Auxiliary variable; $Y$ : Positive variable; $X$ : Binary variable. Then:

$$
Z=X \times Y \text {. }
$$

We can succeed by adding the following constrains to the non-linear model for obtaining a linear mode:

$$
\begin{aligned}
& Z \geq Y-M(1-X), \\
& Z \leq Y+M(1-X), \\
& Z \leq M X,
\end{aligned}
$$

where:

$$
\begin{aligned}
& X \in \text { Binary, } \quad Y \in \text { Integer } \\
& Z \in \text { Integer, } \quad M: \text { Big positive number. }
\end{aligned}
$$

\section{Computational results}

The results of a SC that consists of one plant, two crossdocks, and four markets with a five-period horizon were computed. The code for this Mixed Integer Program (MIP) was written in Xpress MP suite [53], which uses the branch and cut method [54]. In general, the computational time increases due to a large number of capacitating constraints and the huge number of binary and integer variables, encountered even for a small-sized SC problem.

\subsection{Sensitivity analysis}

Sensitivity analysis was carried out as a generic problem of SC for perishable products under the truckload discount scheme. There are four markets, two warehouses, one plant, and five time periods that have been considered here for sensitivity analysis. The data [21] used for sensitivity analysis is illustrated in Tables 2, 3, and, 4. This study calculated the percentage of changes in the decision variables by varying each input parameter separately with respect to the base case. The base cases were marked by ' $*$ '. The value of the input parameter increased and decreased by $5 \%$ and $10 \%$ from the base case. Table 5 indicates that there is a sharp reduction in $\mathrm{SC}$ on the number of orders, going from the 2 nd case $\left(F C_{f}=570\right)$ to the base case. This occurs because when the transportation cost increases, it is better to decrease the number of shipments, which automatically reduces the number of orders. As the replenishment period increases, the $\mathrm{HC}$ holding costs also increase. Such discontinuities will occur at discrete $F C_{f}$ and $F C_{h}$ values, and the allocation of units changes at such points. Table 5 provides the following sensitive analysis:

1. If the fixed cost per truck $\left(F C_{f}\right.$ or $\left.F C_{h}\right)$ increases by $5 \%$ (see row 1 of Table 5 ), then the expected total cost increases by $1.5 \%$ (see last row of Table 5);

2. If the Fixed Transportation Cost (FTC) increases by $5 \%$ (see column 5 with respect to the base column of Table 5), then the total expected cost increases by $1.5 \%$ (see last row of column 5 with respect to the base column of Table 5);

3. If the FTC increases by $10 \%$ (see Column 6 with

Table 2. Data matrix for market-period demand.

\begin{tabular}{cccccc}
\hline & \multicolumn{5}{c}{ Period } \\
\cline { 2 - 6 } Market & $\mathbf{1}$ & $\mathbf{2}$ & $\mathbf{3}$ & $\mathbf{4}$ & $\mathbf{5}$ \\
\hline $\mathbf{1}$ & 40 & 55 & 52 & 48 & 35 \\
$\mathbf{2}$ & 45 & 42 & 68 & 75 & 25 \\
$\mathbf{3}$ & 50 & 62 & 48 & 62 & 38 \\
$\mathbf{4}$ & 65 & 75 & 45 & 54 & 65 \\
\hline
\end{tabular}

Table 3. Data for warehouse-market distance matrix.

\begin{tabular}{ccccc}
\hline & \multicolumn{4}{c}{ Market } \\
\hline Warehouse & 1 & 2 & 3 & 4 \\
$\mathbf{1}$ & 12 & 6 & 5 & 5 \\
$\mathbf{2}$ & 9 & 4 & 4 & 7 \\
\hline
\end{tabular}

Table 4. Data for plant warehouse distance matrix.

\begin{tabular}{cll}
\hline & \multicolumn{2}{l}{ Warehouse } \\
\cline { 2 - 3 } Plant & 1 & 2 \\
$\mathbf{1}$ & 5 & 6 \\
\hline
\end{tabular}


Table 5. Sensitivity analysis when the fixed cost per truck changes by $5 \%$.

\begin{tabular}{cccccc}
\hline \multirow{2}{*}{ Cost parameters $(\$)$} & \multicolumn{5}{c}{$\boldsymbol{F} \boldsymbol{C}_{\boldsymbol{f}}, \boldsymbol{F} \boldsymbol{C}_{\boldsymbol{h}}$} \\
\cline { 2 - 6 } & $\mathbf{5 4 0 , 3 6 0}$ & $\mathbf{5 7 0 , 3 8 0}$ & $\mathbf{6 0 0 , 4 0 0}$ & $\mathbf{6 3 0 , 4 2 0}$ & $\mathbf{6 6 0 , 4 4 0}$ \\
\hline SCP & 0 & 0 & 400 & 0 & 0 \\
FTC & -8.5 & -3.4 & 1100 & 5 & 10 \\
VTC & 0.6 & 0.6 & 156 & 0 & 0 \\
HNC & -0.2 & -0.2 & 480 & 0 & 0 \\
HC & -8.1 & -8.1 & 436 & 0 & 0 \\
LC & -1.2 & -1.2 & 352 & 0 & 0 \\
SC & 5.3 & 5.3 & 470 & 0 & 0 \\
& & & & & \\
{$[E T C]$} & -3 & -1.5 & 2675 & 1.5 & 3 \\
\hline
\end{tabular}

*: Base column

Table 6. Sensitivity analysis when Full Truck Load (FTL) changes by $5 \%$.

\begin{tabular}{cccccc}
\hline \multirow{2}{*}{ Cost parameters $(\$)$} & \multicolumn{5}{c}{ FTL } \\
\cline { 2 - 6 } & $\mathbf{2 7 0}$ & $\mathbf{2 8 5}$ & $\mathbf{3 0 0}^{*}$ & $\mathbf{3 1 5}$ & $\mathbf{3 3 0}$ \\
\hline SCP & 0 & 0 & 400 & 0 & 0 \\
FTC & 3.3 & 5 & 1100 & -1.7 & 1.7 \\
VTC & 2.6 & 2.1 & 156 & 1 & -0.2 \\
HNC & -0.1 & -0.2 & 480 & -0.1 & -0.2 \\
HC & -11.9 & -13 & 436 & -8.9 & -13 \\
LC & -1.1 & -1.9 & 352 & -0.7 & -1.9 \\
SC & 5.3 & 5.3 & 470 & 5.3 & 5.3 \\
& & & & & \\
{$[E T C]$} & 0.1 & 0.3 & 2675 & -1 & -0.8 \\
\hline
\end{tabular}

*: Base column

respect to the base column of Table 5), then total expected cost increases by $3 \%$ (see last row of column 6 with respect to the base column of Table 5);

4. If holding cost decreases by $8.1 \%$ (see row 6 of column 3 with respect to the base column of Table 5), then the total expected cost decreases by $1.5 \%$ (see last row of column 3 with respect to the base column of Table 5);

5. If holding cost decreases, the number of orders placed increases. Therefore, the setup cost per order will decrease;

6. If the cost of variable transportation increases (see row 4 of column 3 with respect to the base column of Table 5), then the number of orders placed will decrease, resulting in an increase in setup cost per order (see row 8 of column 3 with respect to the base column).

Similar discontinuities exist when $F T L, H C, L C, S C_{p}$, and $O C_{m}$ are allowed to change for the same reasons
(Tables $6-10$ ). Table 6 clearly states that if the FTL increases by $5 \%$ (see row 1 of Table 6 ), then the total expected cost also decreases (see last row of columns 2 and 3 , bases 5 and 6 of Table 6 ). Table 7 clearly shows that if holding cost per unit $(H C)$ increases by $5 \%$ (see row 1 of Table 7 ), then the total expected cost increases by $0.6-0.7 \%$ (see last row of Table 7 ). Table 8 indicates that if the lost cost per unit $(L C)$ increases by $5 \%$ (see row 1 of Table 8 ), then the total expected cost increases by $0.5-0.6 \%$ (see last row of Table 8 ). Table 9 concludes that if setup cost per production period $\left(S C_{p}\right)$ increases by $5 \%$ (see row 1 of Table 9 ), then the total setup cost increases by $0.6-0.7 \%$ (see last row of Table 9 ). Table 9 shows that if the setup cost per order $\left(O C_{m}\right)$ increases by $5 \%$ (see row 1 of Table 10), then the total expected cost increases by $0.7-0.8 \%$ (see last row of Table 10).

Although the total cost does not vary proportionally with each parameter, the variance is symmetric about the base case. Apart from FLT, it is observed that variance will be symmetric about the base case, even though the total cost $[E T C]$ is not going to change significantly because of a change in other 
Table 7. Sensitivity analysis when Holding Cost (HC) per unit changes by $5 \%$.

\begin{tabular}{cccccc}
\hline \multirow{2}{*}{ Cost parameters (\$) } & \multicolumn{5}{c}{ HC } \\
\cline { 2 - 6 } & $\mathbf{9}$ & $\mathbf{9 . 5}$ & $\mathbf{1 0}$ & $\mathbf{1 0 . 5}$ & $\mathbf{1 1}$ \\
\hline SCP & 0 & 0 & 400 & 0 & 0 \\
FTC & 0 & 0 & 1100 & 1.7 & 1.7 \\
VTC & 0 & 0 & 156 & 0.6 & 0.6 \\
HNC & 0 & 0 & 480 & -0.2 & -0.2 \\
HC & -10 & -5 & 436 & -3.6 & 1 \\
LC & 0 & 0 & 352 & -1.2 & -1.2 \\
SC & 0 & 0 & 470 & 5.3 & 5.3 \\
& & & & & \\
*. BTC $]$ & -1.3 & -0.7 & 2675 & 0.6 & 1.3 \\
\hline
\end{tabular}

Table 8. Sensitivity analysis when Lost Cost/unit (LC) changes by $5 \%$.

\begin{tabular}{cccccc}
\hline \multirow{2}{*}{ Cost parameters $(\$)$} & \multicolumn{5}{c}{ LC } \\
\cline { 2 - 6 } & $\mathbf{2 2 . 5}$ & $\mathbf{2 3 . 7 5}$ & $\mathbf{2 5}$ & $\mathbf{2 6 . 2 5}$ & $\mathbf{2 7 . 5}$ \\
\hline SCP & 0 & 0 & 400 & 0 & 0 \\
FTC & 0 & 0 & 1100 & 0 & 0 \\
VTC & 0 & 0 & 156 & 0 & 0 \\
HNC & 0 & 0 & 480 & 0 & 0 \\
HC & 0 & 0 & 436 & 0 & 0 \\
LC & -10 & -5 & 352 & 5 & 10 \\
SC & 0 & 0 & 470 & 0 & 0 \\
& & & & & \\
{$[E T C]$} & -1.1 & -0.6 & 2675 & 0.6 & 1.1 \\
\hline
\end{tabular}

*: Base column

Table 9. Sensitivity analysis when setup cost per production period $\left(S C_{p}\right)$ changes by $5 \%$.

\begin{tabular}{cccccc}
\hline \multirow{2}{*}{ Cost parameters $(\$)$} & $\mathbf{5 0}$ & $\mathbf{9 5 0}$ & $\mathbf{1 0 0 0}_{\boldsymbol{p}}$ & $\mathbf{1 0 5 0}$ & $\mathbf{1 1 0 0}$ \\
\cline { 2 - 6 } SCP & $\mathbf{9 0 0}$ & -5 & 400 & 5 & 10 \\
FTC & 0 & 0 & 1100 & 0 & 0 \\
VTC & 0 & 0 & 156 & 0 & 0 \\
HNC & 0 & 0 & 480 & 0 & 0 \\
HC & 0 & 0 & 436 & 0 & 0 \\
LC & 0 & 0 & 352 & 0 & 0 \\
SC & 0 & 0 & 470 & 0 & 0 \\
*. Base column & -1.3 & -0.6 & 2675 & 0.6 & 1.3 \\
\hline ETC $]$ & & & & &
\end{tabular}

Table 10. Sensitivity analysis when setup cost/order $\left(O C_{m}\right)$ changes by $5 \%$.

\begin{tabular}{cccccc}
\hline \multirow{2}{*}{ Cost parameters (\$) } & \multicolumn{5}{c}{$\boldsymbol{O \boldsymbol { C } _ { \boldsymbol { m } }}$} \\
\cline { 2 - 6 } & $\mathbf{2 7 0}$ & $\mathbf{2 8 5}$ & $\mathbf{3 0 0}$ & $\mathbf{3 1 5}$ & $\mathbf{3 3 0}$ \\
\hline SCP & 0 & 0 & 400 & 0 & 0 \\
FTC & 1.7 & 1.7 & 1100 & 0 & 0 \\
VTC & 0.6 & 0.6 & 156 & 0 & 0 \\
HNC & -0.2 & -0.2 & 480 & 0 & 0 \\
HC & -8.1 & -8.1 & 436 & 0 & 0 \\
LC & -1.2 & -1.2 & 352 & 0 & 0 \\
SC & -5.3 & 0 & 470 & 5 & 10 \\
& & & & & \\
{$[E T C]$} & -1.5 & -0.7 & 2675 & 0.7 & 1.4 \\
\hline
\end{tabular}

*: Base column 
Table 11. Sensitivity analysis when total demand $\left(\sum D_{m}\right)$ changes by $5 \%$.

\begin{tabular}{cccccc}
\hline \multirow{2}{*}{ Cost parameters $(\$)$} & \multicolumn{5}{c}{$\boldsymbol{\Sigma} \boldsymbol{D}_{\boldsymbol{m}}$} \\
\cline { 2 - 6 } & $\mathbf{1 0 9 8}$ & $\mathbf{1 1 5 9}$ & $\mathbf{1 2 2 0}$ & $\mathbf{1 2 8 1}$ & $\mathbf{1 3 4 2}$ \\
\hline SCP & 0 & 0 & 400 & 0 & 0 \\
FTC & 1.7 & -1.7 & 1100 & 5 & 3.3 \\
VTC & -8.5 & -3.3 & 156 & 6.4 & 10.9 \\
HNC & -8.6 & -4.3 & 480 & 4 & 8.4 \\
HC & -13 & -9.9 & 436 & -13 & -10.9 \\
LC & -1.9 & -1.1 & 352 & -1.9 & -0.4 \\
SC & 5.3 & 5.3 & 470 & 5.3 & 5.3 \\
& & & & & \\
{$[E T C]$} & -2.3 & -2 & 2675 & 1.1 & 1.9 \\
\hline
\end{tabular}

*: Base column

Table 12. Variation in total cost $[E T C]$.

\begin{tabular}{|c|c|c|c|c|c|c|c|c|}
\hline \multirow[b]{2}{*}{ Serial no. } & \multicolumn{4}{|c|}{ Low demand } & \multicolumn{4}{|c|}{ High demand } \\
\hline & $F T L$ & $F C_{f}$ & $F C_{h}$ & {$[E T C](\$)$} & $F T L$ & $F C_{f}$ & $F C_{h}$ & {$[E T C](\$)$} \\
\hline 1 & 150 & 450 & 300 & 3088 & 350 & 750 & 500 & 5234 \\
\hline 2 & 250 & 600 & 400 & 3010 & 450 & 900 & 600 & 4931 \\
\hline 3 & 350 & 750 & 500 & 3222 & 550 & 1050 & 700 & 5098 \\
\hline 4 & 450 & 900 & 500 & 3321 & 650 & 1200 & 800 & 5279 \\
\hline
\end{tabular}

parameters. In this regard, some exceptions can be observed including 3\% variance in FTL with $2.3 \%$ variance in total demand that affects less than $1.5 \%$ of the total cost. Even though the change in $[E T C]$ is not substantial, the distribution of costs among FTC, $\mathrm{HC}$, and SC varies noticeably. This implies that the shipping schedule is altered due to the discontinuities mentioned above.

Table 8 shows similar behavior on either side of the base case for HC and SC. This appears odd since a decrease in demand should reduce the number of orders. However, an increase in $\mathrm{SC}$ is more than offset by a reduction in $\mathrm{HC}$, thereby reducing [ETC]. Table 11 indicates that if the total demand increases by $5 \%$ (see row 1 of Table 11), then the total expected cost also increases.

\section{Analysis}

\subsection{Fleet selection}

In reality, freight transport companies would provide a variety of carriers with different capacities. In the proposed model, the cost structure reflects Economies of Scale (EOS) for such carriers. Table 12 shows that it becomes relatively cheaper to hire trucks with a larger capacity.

At low demand, it can be concluded that FTL at 250 is the cheapest option for buyers. In the same way,
FTL at 450 is the cheapest option for the buyer during high demand available in the market. On the basis of Table 10, the following can be concluded:

1. At low demand in the market:

$$
\text { FTL250 < FTL150 < FTL350 < FTL450, }
$$

2. At high demand in the market:

$$
\text { FTL450 < FTL350 < FTL550 < FTL650. }
$$

The trend observed in the proposed framework is validated based on obtained results of Dolgui et al. (2018), which are in agreement with those obtained in the current study [21].

\subsection{Centralized versus decentralized $S C$ for perishable products}

There are two approaches to the decision-making modeling of a SC management for perishable products: a centralized SC model and a decentralized SC model. Practically, it is hard to find any SC management model that has either centralized or decentralized approaches because both approaches have their own advantages and disadvantages. The efficiency of either centralized or decentralized SC management approach mainly depends upon the specific environment and the decision taken by decision-makers. Therefore, the role of decision-makers in both approaches decides the 
Table 13. Centralized vs. decentralized supply chain.

\begin{tabular}{|c|c|c|c|}
\hline & & Decentralized supply chain & Centralized supply chain \\
\hline Decision making & $\begin{array}{l}\text { Decisic } \\
\text { local it }\end{array}$ & $\begin{array}{l}\text { n taken based on their (SC) } \\
\text { formation }\end{array}$ & $\begin{array}{l}\text { Decision taken based on their }(\mathrm{SC}) \\
\text { central information }\end{array}$ \\
\hline $\begin{array}{l}\text { Elements of } \\
\text { supply chain }\end{array}$ & $\begin{array}{l}\text { Each e } \\
\text { treatec } \\
\text { aiming } \\
\text { rate wi } \\
\text { system }\end{array}$ & $\begin{array}{l}\text { lements of the supply chain is } \\
\text { as an individual company } \\
\text { to minimize its own outdate } \\
\text { th no consideration of the } \\
\text {-wide outdate rate }\end{array}$ & $\begin{array}{l}\text { Each elements of the supply chain is } \\
\text { treated as an global company aiming } \\
\text { to minimize its global outdate rate } \\
\text { with consideration of the system-wide } \\
\text { outdate rate }\end{array}$ \\
\hline $\begin{array}{l}\text { Mathematical model: } \\
\text { Objective function } \\
\text { (i.e., system outdate } \\
\text { rate) and constant }\end{array}$ & $\begin{array}{l}F_{\text {decent }} \\
\text { Subjec } \\
\max \{f \\
\text { where: } \\
g: \\
E_{p}: \\
O R_{g}: \\
S R_{g}: \\
\varphi:\end{array}$ & $\begin{array}{l}\text { alized }=\sum_{g=0}^{G} \min \left\{E_{p}\left(O R_{g}\right)\right\} \\
\text { to: } \\
\left.p\left(S R_{g}\right)\right\} \leq 1-\varphi \text { for } g=0, \cdots, G \\
\text { Supply chain entity, } g=0, \cdots, G \\
\text { Expected value function with respect to } \\
\text { the stochastic demand distribution } p \\
\text { The outdated rate for entity ' } g \text { ' } \\
\text { The shortage rate for entity ' } g \text { ' } \\
\text { The fill rate service measure (fraction } \\
\text { of demand that can be satisfied } \\
\text { immediately from the stock on hand) }\end{array}$ & $\begin{array}{l}F_{\text {centralized }}=\min \left\{\sum_{g=0}^{G} E_{p}\left(O R_{g}\right)\right\} \\
\text { Subject to } \\
\max \left\{E_{p}\left(S R_{g}\right)\right\} \leq 1-\varphi \text { for } g=0, \cdots, G\end{array}$ \\
\hline
\end{tabular}

success of the SC management for perishable products. The basic concept of centralized and decentralized $\mathrm{SC}$ with their mathematical model is illustrated in Table 13.

Generally, the total cost incurred for the centralized SC management is lower than that for decentralized SC. This study analyzed the cost associated with vendors and buyers in the implementation course of both SC approaches and provided a comparative analysis. To conduct a comparative analysis of centralized and decentralized approaches, FTL is used as a variable while keeping other parameters as constant. In this research article, an assumption was made during the course of implementing the decentralized approach from the buyer's point of view. At different values of FTL, the cost incurred by vendors and buyers has a significant margin. Therefore, different discount schemes should be implemented for handling this situation. The $\mathrm{SC}$ management with minimum vendor cost is desired from the vendor's point of view.

Conducted analysis suggests that, from the vendor's point of view, the total cost reduces while increasing the truckload, which means that the cost reduction by economics of scale is significantly greater than the additional holding cost associated with the buyer. For the same reason, a similar trend is also observed in the case of a centralized approach or an integrated chain.

The SC management with minimum buying costs is desired from the buyer's point of view. Accordingly, the total cost is observed in different models and that the minimum total cost is observed at FTL 350 . According to the analysis, at FTL 350, the buyer's perspective and centralized chain coincide. The vendor should optimize the quantity of order so that the transportation cost would be minimum, which leads to a win-win situation for the vendor; otherwise, the vendor should offer some discount scheme to the buyer to shift the buyer's point of view to the centralized SC.

In this research, an analysis based on the total cost reduction for the buyer and vendor is carried out. The analysis shows that the buyer cost remains constant throughout the varying FLT because holding cost is independent of truck capacity. Therefore, the margin between the centralized SC and the buyer's point of view demonstrates the cost reduction pertaining to the vendor. The margin between the buyer's point of view and the centralized chain explores the facility of discount that should be provided by the vendor for the buyer. An increase in the buyer cost should be compensated by providing some discount scheme for 
Table 14. Lead time versus total cost.

\begin{tabular}{cc}
\hline $\boldsymbol{L}_{\boldsymbol{t}}$ & {$[\boldsymbol{E} \boldsymbol{T C}](\$)$} \\
\hline 0 & 4000 \\
1 & 4735 \\
2 & 4995 \\
3 & 5296 \\
\hline
\end{tabular}

the buyer from the vendor; this scheme will reduce the costs for the vendor.

The problem of fleet selection has been analyzed in this research article from the vendor's perspective. In the case of the decentralized chain, the maximum value of VPOVC and BPOVC is observed at FTL 250. The minimum value from the vendor and buyer's points of view is observed at the same point in the centralized chain, and this minimum FTL value also acts as an operating point. The difference in the cost of centralized and decentralized chains is an additional cost that is incurred during the trading of the vendor and buyer when shifting from the vendor's point of view to the buyer's. However, in the case of centralized chain, this additional cost is a balance between them. Therefore, from the buyer's point of view, FTL 150 and FTL 350 are the most suitable options in this case. On the other hand, a shift from FTL 250 is allowed only when one considers centralized decisionmaking techniques. At last, on the basis of analysis, it can be concluded that the selection of fleet mainly depends upon the approach of SC, i.e., centralized or decentralized.

An important aspect of fleet selection that has been ignored is the lead time (assumption). In general, the total cost is proportionate to lead time (see Table 14). Thus, alternate modes of transportation could be explored to reduce the lead time. The change of transportation mode will be accepted if the profit earned by the manufacturer compensates for the charges that arise from changing the mode of transport, which also reduces the lead time. However, in general, a move towards longer lead times is not recommended even if it results in the total cost reduction.

\subsection{The structure of cross-docks}

The flow of goods at a particular point of time defines the capacity and the position of cross-docking. The characteristics of cross-docking include the number of cross-docks, shape of cross-dock, and assignment of carrying capacity; these characteristics mainly depend upon the receiving and shipping units and assignments delivered from door to trailers. In general, the number of cross-docks equals that of outbound trailers. The number of required receiving doors is determined on the basis of incoming and outgoing trailers and unloading and loading time of the respective trailers. Unloading of goods takes a shorter amount of time than the loading of goods; hence, to obtain a smooth flow of goods, the fraction of receiving doors usually ranges from $0.2-0.5$. For a relatively few doors (up to 150), the shape I is the most economical. As the number of doors increases, the shapes $\mathrm{T}(150-250)$ and $\mathrm{X}$ (more than 250) become preferable [55]. The trailers are assigned to doors so that the average distance traveled by the units can be minimized, because the distance traveled is proportionate to the labor cost.

Consider a SC with ' $p$ ' plants, ' $c$ ' cross docks, and ' $m$ ' markets. Let $P(p)$ be a set of plants and $M(m)$ a set of markets connected to cross-dock ' $c$ '. $R_{p c}$ and $R_{c m}$ represent the door numbers assigned to plant ' $p$ ' and market ' $m$ ' at cross-dock ' $c$ ', respectively. One full truck is assigned to one door. This could vary based on FTL and the ratio of loading to unloading time.

$$
\begin{array}{ll}
R_{p c}=\max \left\{\left(N_{p c t}^{f 1}\right)+\left(N_{p c t}^{h 1}\right)\right\} & \forall p \in P, c, \\
R_{c m}=\max \left\{\left(N_{c m t}^{f 2}\right)+\left(N_{c m t}^{h 1}\right)\right\} & \forall m \in M, c, \\
N D_{c}=\sum_{p=1}^{P} R_{p c}+\sum_{m=1}^{M} R_{c m} . &
\end{array}
$$

The number of inbound and outbound trailers at each cross-dock is determined through Eqs. (28) to (30). Let NDc represent the total number of doors at cross-dock ' $c$ '. Then, based on the value of NDc, the shape of the cross dock can be determined.

\subsection{Cross-docking verses warehousing}

It is unusual for SC to only have cross docks; a network of warehouses and cross-docks is more common. There is no quantitative formulation that would facilitate deciding whether cross-docking or warehousing is beneficial. Such decisions are largely based on qualitative analysis. Some of the factors that play a major role in this analysis are discussed below:

1. The rate of consumption: Fast-Moving Consumer Goods (FMCG) have a high rate of consumption and are more suitable for cross-docking, since they do not need to be stored and could be directly shipped to the markets;

2. Perishability: Because of lost costs incurred for perishable products due to deterioration, it is desirable for them to be cross-docked since the time spent on inventory directly raises the lost cost;

3. Variance in demand: For a product with large variance in demand, it would be more suitable to keep it as inventory in the warehouse and satisfy the related orders with stock. However, if the product's demand is stable, then cross-docking gets better;

4. Lead Time: It is important to keep the service level and the service time at a certain level. As 
the lead time increases, it becomes more difficult to achieve this objective. Moreover, the variance in demand increases with the lead time and, hence, a warehouse would be more beneficial in such cases with longer lead times;

5. Centralized/Decentralized SC: In a decentralized SC, it becomes more difficult to synchronize the timing of production and transportation of units with the orders of the retailer. Warehouses might be more suitable in such cases if the factors such as lead time and demand variance become unfavorable to cross-docking.

\section{Conclusions and future research}

The proposed model shows the significance of Economies of Scale (EOS) in transportation for lot sizing problems. The problems related to fleet selection model were discussed, and the corresponding optimum truckload capacity was also identified. The proposed model was applicable to scenarios with variable demand (due to its robust nature as discussed in Section 3). There was no mathematical formulation to decide whether cross-docking or warehousing would be more suitable for the given supply chain. However, the study of the chain structure that considers the factors mentioned in Section 4 provided a decision-making tool. The proposed model was easily applicable to cases with uncertain or probabilistic demand scenarios without incurring substantial additional costs and without altering the optimal shipping schedule. The results of the general analyses carried out in this research are as follows:

1. If the fixed cost per truck $\left(F C_{f}, F C_{h}\right)$ increases by $5 \%$, then the total expected cost increases by $1.5 \%$;

2. If Full Truck Load (FTL) increases by $5 \%$, then the total expected cost also increases;

3. If holding cost per unit (HC) increases by $5 \%$, then the total expected cost increases by $0.6-0.7 \%$;

4. If the lost cost per unit (LC) increases by $5 \%$, then the total expected cost increases by $0.5-0.6 \%$;

5. If setup cost per production period $\left(S C_{p}\right)$ increases by $5 \%$, then the total expected cost increases by $0.6-0.7 \%$;

6. If setup cost per order $\left(O C_{m}\right)$ increases by $5 \%$, then the total expected cost increases by $0.7-0.8 \%$;

7. If total demand $\left(\sum D_{m}\right)$ increases by $5 \%$, then the total expected cost also increases.

In general, cross-docking is more beneficial when units shipped are Fast-Moving Consumer Good (FMCG) or perishable. However, the supply chains usually consist of both of these structures. Thus, it becomes important to examine supply chains that comprise both cross-docks and warehouses. Another interesting point to note in relation to cross-docks includes delivery and pickup time windows [55]. However, it would result in a much more complex optimization problem.

This model can easily be extended to accommodate multiple products. However, it already consists of a large number of variables, due to which the computational time increases rapidly with every additional products introduced to the chain. For the same reason, it becomes difficult to do calculations for supply chains with a large number of plants, crossdocks, and markets. Hence, appropriate heuristics need to be developed to model large multi-product supply chains that could provide near-optimal results in a relatively short amount of time.

\section{Acknowledgement}

We are highly grateful to the Editor-in-Chief, Editorial team, and anonymous referees for their constructive comments to improve the overall quality of the paper.

\section{References}

1. Nobari, A. and Kheirkhah, A. "Integrated and dynamic design of sustainable closed-loop supply chain network considering pricing", Scientia Iranica, 25(1), pp. $410-430$ (2018).

2. Hajiaghaei-Keshteli, M. and Fathollahi-Fard, A.M.F. "Sustainable closed-loop supply chain network design with discount supposition", Neural Computing and Applications, pp. 1-35. (2018). DOI: https://doi.org/10.1007/s00521-018-3369-5

3. Simchi-Levi, D., Kaminsky, P., Simchi-Levi, E., and Shankar, R., Designing and Managing the Supply Chain: Concepts, Strategies and Case Studies, Tata McGraw-Hill Education, Third Edn. (2008).

4. Farahani, R.Z., Rezapour, S., Drezner, T., and Fallah, S. "Competitive supply chain network design: An overview of classifications, models, solution techniques and applications", Omega, 45, pp. 92-118 (2014).

5. Koç, Ç. "An evolutionary algorithm for supply chain network designs with assembly line balancing", Neural Computing and Applications, 28(11), pp. 3183-3195 (2017).

6. Schmidt, G. and Wilhelm, W.E. "Strategic, tactical and operational decisions in multi-national logistics networks: a review and discussion of modelling issues", International Journal of Production Research, 38(7), pp. 1501-1523 (2000).

7. Fathollahi-Fard, A.M. and Hajiaghaei-Keshteli, M. "A stochastic multi-objective model for a closed-loop supply chain with environmental considerations", Applied Soft Computing, 69, pp. 232-249 (2018). 
8. Eydi, A., Fazayeli, S., and Ghafouri, H. "Multi-period configuration of forward and recerse integrated supply chain networks with the choice of transportation mode", Scientia Iranica, 27(2), pp. 935-955 (2020). DOI: $10.24200 /$ SCI.2018.5261.1175

9. Mokhtari, H., Naimi-Sadigh, A., and Salmasnia, A. "A computational approach to economic production quantity model for perishable products with backordering shortage and stock-dependent demand", Scientia Iranica, 24(4), pp. 2138-2151 (2017).

10. Devika, K., Jafarian, A., and Nourbakhsh, V. "Designing a sustainable closed-loop supply chain network based on triple bottom line approach: A comparison of meta-heuristics hybridization techniques", European Journal of Operational Research, 235(3), pp. 594-615 (2014).

11. De La Vega, D.S., Vieira, J.G.V., Toso, E.A.V., and De Faria, R.N. "A decision on the truckload and less-thantruckload problem: An approach based on MCDA", International Journal of Production Economics, 195, pp. 132-145 (2018).

12. Bruno, G., Genovese, A., and Piccolo, C. "The capacitated lot sizing model: A powerful tool for logistics decision making", International Journal of Production Economics, 155, pp. 380-390 (2014).

13. Chandra, P. and Fisher, M.L. "Coordination of production and distribution planning", European Journal of Operational Research, 72(3), pp. 503-517 (1994).

14. Erengüç, Ş.S., Simpson, N.C., and Vakharia, A.J. "Integrated production/distribution planning in supply chains: An invited review", European Journal of Operational Research, 115(2), pp. 219-236 (1999).

15. Li, H. and Meissner, J. "Capacitated dynamic lot sizing with capacity acquisition", International Journal of Production Research, 49(16), pp. 4945-4963 (2011).

16. Rezaei, J. and Davoodi, M. "A joint pricing, lot-sizing, and supplier selection model", International Journal of Production Research, 50(16), pp. 4524-4542 (2012).

17. Amorim, P., Belo-Filho, M., Toledo, F., Almeder, C., and Almada-Lobo, B. "Lot sizing versus batching in the production and distribution planning of perishable goods", International Journal of Production Economics, 146, pp. 208-218 (2013).

18. Govindan, K., Jafarian, A., Khodaverdi, R., and Devika, K. "Two-echelon multiple-vehicle locationrouting problem with time windows for optimization of sustainable supply chain network of perishable food", International Journal of Production Economics, 152, pp. 9-28 (2014).

19. Ma, Z.J., Wu, Y., and Dai, Y. "A combined order selection and time-dependent vehicle routing problem with time widows for perishable product delivery", Computers \& Industrial Engineering, 114, pp. 101113 (2017).

20. Azadeh, A., Elahi, S., Farahani, M.H., and Nasirian, B. "A genetic algorithm-Taguchi based approach to inventory routing problem of a single perishable product with transshipment", Computers \& Industrial Engineering, 104, pp. 124-133 (2017).

21. Dolgui, A., Tiwari, M.K., Sinjana, Y., Kumar, S.K., and Son, Y.J. "Optimizing integrated inventory policy for perishable items in a multi-stage supply chain", International Journal of Production Research, 56(12), pp. 902-925 (2018).

22. Gitinavard, H., Ghodsypour, S.H., and Shirazi, M.A. "A bi-objective multi-echelon supply chain model with Pareto optimal points evaluation for perishable products under uncertainty", Scientia Iranica, 26(5), pp. 2952-2970 (2019). DOI: 10.24200/SCI.2018.5047.1060

23. Fathollahi-Fard, A.M., Hajiaghaei-Keshteli, M., and Mirjalili, S. "Multi-objective stochastic closed-loop supply chain network design with social considerations", Applied Soft Computing, 71, pp. 505-525 (2018).

24. Fathollahi-Fard, A.M., Hajiaghaei-Keshteli, M., and Mirjalili, S. "Hybrid optimizers to solve a tri-level programming model for a tire closed-loop supply chain network design problem", Applied Soft Computing, 70, pp. 701-722 (2018).

25. Musavi, M. and Bozorgi-Amiri, A. "A multi-objective sustainable hub location-scheduling problem for perishable food supply chain", Computers \& Industrial Engineering, 113, pp. 766-778 (2017).

26. Fathollahi-Fard, A.M. and Hajiaghaei-Keshteli, M. "A bi-objective partial interdiction problem considering different defensive systems with capacity expansion of facilities under imminent attacks", Applied Soft Computing, 68, pp. 343-359 (2018).

27. Hajiaghaei-Keshteli, M. and Fathollahi-Fard, A.M. "A set of efficient heuristics and meta-heuristics to solve a two-stage stochastic bi-level decision-making model for the distribution network problem", Computers \& Industrial Engineering, 123, pp. 378-395 (2018).

28. Samadi, A., Mehranfar, N., Fathollahi Fard, A.M., and Hajiaghaei-Keshteli, M. "Heuristic-based metaheuristic to address a sustainable supply chain network design problem", Journal of Industrial and Production Engineering, 35(2), pp. 102-117 (2018).

29. Fathollahi-Fard, A.M., Hajiaghaei-Keshteli, M., and Tavakkoli-Moghaddam, R. "The Social Engineering Optimizer (SEO)", Engineering Applications of Artificial Intelligence, 72, pp. 267-293 (2018c).

30. Stenmarck, A., Jensen, C., Quested, T., and Moates, G. "Estimation of European food waste levels", FUSIONS: EU Project under European Community's Seventh Framework Programme Under Grant Agreement No 311972 (2016). (Retrieved at http://www.eu-fusions.org/phocadownload/Publications/Estimates\%20of\%20European\%20food\%20waste \%20levels.pdf on 22 Dec 2018).

31. Goyal, S.K. and Giri, B.C. "Recent trends in modeling of deteriorating inventory", European Journal of Operational Research, 134(1), pp. 1-16 (2001). 
32. Ghare, P. and Schrader, G. "A model for exponentially decaying inventory", Journal of Industrial Engineering, 14(5), pp. 238-243 (1963).

33. Nahmias, S. "Perishable inventory theory: A review", Operations Research, 30(4), pp. 680-708 (1982).

34. Hsu, V.N. "Dynamic economic lot size model with perishable inventory", Management Science, 46(8), pp. 1159-1169 (2000).

35. Abad, P. "Optimal lot size for a perishable good under conditions of finite production and partial backordering and lost sale", Computers \& Industrial Engineering, 38, pp. 457-465 (2000).

36. Abad, P.L. "Optimal pricing and lot-sizing under conditions of perishability, finite production and partial backordering and lost sale", European Journal of Operational Research, 144, pp. 677-685 (2003).

37. Teng, J.T., Cárdenas-Barrón, L.E., Chang, H.J., Wu, J., and $\mathrm{Hu}, \mathrm{Y}$. "Inventory lot-size policies for deteriorating items with expiration dates and advance payments", Applied Mathematical Modelling, 40(1920), pp. 8605-8616 (2016).

38. Hiassat, A., Diabat, A., and Rahwan, I. "A genetic algorithm approaches for location-inventory-routing problem with perishable products", Journal of Manufacturing Systems, 42, pp. 93-103 (2017).

39. Sahebjamnia, N., Fathollahi-Fard, A.M., and Hajiaghaei-Keshteli, M. "Sustainable tire closed-loop supply chain network design: Hybrid metaheuristic algorithms for large-scale networks", Journal of Cleaner Production, 196, pp. 273-296 (2018).

40. Karimi, B., Fatemi Ghomi, S., and Wilson, J. "The capacitated lot sizing problem: A review of models and algorithms", Omega, 31(5), pp. 365-378 (2003).

41. Yano, C.A. and Lee, H.L. "Lot sizing with random yields: A review", Operations Research, 43(2), pp. 311-334 (1995).

42. Ben-Daya, M., Darwish, M., and Ertogral, K. "The joint economic lot-sizing problem: Review and extensions", European Journal of Operational Research, 185(2), pp. 726-742 (2008).

43. Robinson, P., Narayanan, A., and Sahin, F. "Coordinated deterministic dynamic demand lot-sizing problem: A review of models and algorithms", Omega, 37(1), pp. 3-15 (2009).

44. Önal, M., Romeijn, H.E., Sapra, A., and Van den Heuvel, W. "The economic lot-sizing problem with perishable items and consumption order preference", European Journal of Operational Research, 244, pp. 881-891 (2015).

45. Lee, W. "A joint economic lot size model for raw material ordering, manufacturing setup, and finished goods delivering", Omega, 33, pp. 163-174 (2005).
46. Pal, A., Chan, F., Mahanty, B., and Tiwari, M. "Aggregate procurement, production, and shipment planning decision problem for a three-echelon supply chain using swarm-based heuristics", International Journal of Production Research, 49, pp. 2873-2905 (2011).

47. Önal, M. "The two-level economic lot-sizing problem with perishable items", Operations Research Letters, 44, pp. 403-408 (2016).

48. Benton, W.C. and Park, S. "A classification of literature on determining the lot size under quantity discounts", European Journal of Operational Research, 92(2), pp. 219-238 (1996).

49. Nahmias, S. and Cheng, Y., Production and Operations Analysis, New York: McGraw-hill, 6 (2009).

50. Ke, G.Y. and Bookbinder, J.H. "Coordinating the discount policies for retailer, wholesaler, and less-thantruckload carrier under price-sensitive demand: A trilevel optimization approach", International Journal of Production Economics, 196, pp. 82-100 (2018).

51. Marandi, F. and Zegordi, S.H. "Integrated production and distribution scheduling for perishable products", Scientia Iranica, 24(4), pp. 2105-2118 (2017).

52. Chung, K.J., Ting, P.S., and Cárdenas-Barrón, L.E. "A simple solution procedure for solving the multidelivery policy into economic production lot size problem with partial rework", Scientia Iranica, Transaction E, Industrial Engineering, 24(5), pp. 2640-2644 (2017).

53. Optimization, D. "Xpress-mp manual" (2002).

54. Guéret, C., Prins, C., and Sevaux, M., Applications of Optimization with Xpress-mp, Dash Optimization Ltd (1999).

55. Chen, P., Guo, Y., Lim, A., and Rodrigues, B. "Multiple cross-docks with inventory and time windows", Computers \& Operations Research, 33(1), pp. 43-63 (2006).

\section{Biographies}

Amit Kumar Sinha is an Assistant Professor at the Department of Mechanical Engineering at Shri Mata Vaishno Devi University, Katra, India-182320. He is also a PhD Scholar from the same University. He received MS degree in Human and Systems Engineering from Ulsan National Institute of Science \& Technology (UNIST), South Korea. He has BTech degree in Manufacturing Engineering from National Institute of Foundry \& Forge Technology (NIFFT), Ranchi, India. He has more than 5 years of teaching and research experience at different levels. He works in the area of evolutionary computing, applications, modeling and simulation of manufacturing system, supply chain management, planning and scheduling of automated manufacturing system, etc. He has published around 10 articles in the leading international journals and is serving 
as a reviewer in international journals including European Journal of Operation Research (EJOR), IJPR, IJPE, Computers and Industrial Engineering, etc.

Ankush Anand is an Associate Professor at the Department of Mechanical Engineering at Shri Mata Vaishno Devi University (SMVDU), Katra, Jammu \& Kashmir-182320, India. He obtained his $\mathrm{PhD}$ in Mechanical Engineering in the area of Life Cycle Engineering. He has more than 12 years of teaching and research experience at different levels. His areas of research interest include sustainable design, design optimization, life cycle engineering, tribology, etc. He has guided a number of U.G and P.G projects and is also supervising $\mathrm{PhD}$ students in the areas of risk mitigation in product design; new product development, and tribology. He has attended several overseas conferences and has published research papers in various international journals of high repute including American Society of Mechanical Engineering (ASME). $\mathrm{He}$ is also a member of ASME and is serving as a reviewer in reputable international journals. 